\section{Identification of Occlusal Prematurity by Clinical Examination and Cone- Beam Computed Tomography}

Naila Aparecida de Godoi Machado', João César Guimarães Henriques², Éverton Ribeiro Lelis ${ }^{1}$, Marcelo Tavares ${ }^{3}$, Guilherme de Araújo Almeida ${ }^{4}$, Alfredo Júlio Fernandes Neto ${ }^{5}$
'Graduate Program, Dental School, UFU - Federal University of Uberlândia, MG, Brazi ${ }^{2}$ Departament os Stomatology and Radiology, Dental School, UFU - Federal University of Uberlândia, MG, Brazil ${ }^{3}$ School of Mathematics, UFU - Federal University of Uberlândia, MG, Brazil ${ }^{4}$ Department of Pediatric Dentistry and Orthodontics, Dental School, UFU - Federal University of Uberlândia, MG, Brazil ${ }^{5}$ Department of Occlusion, Fixed Prosthodontics and Dental Materials, Dental School, UFU - Federal University of Uberlândia, MG, Brazil

Correspondence: Guilherme de Araújo Almeida, Rua Professor Mário Porto, 225, Lídice, 38400-138 Uberlândia, MG, Brasil. Tel: +55-34-3219-4989. e-mail: galmeidaorto@prove.ufu.br

Key Words: dental occlusion, cone-beam computed tomography, centric relation.

\section{Introduction}

Dental professionals must consider the importance of occlusal contacts for the success of dental treatment, maintaining occlusal stability and orofacial harmony, as occlusal interferences may implicate potential damages to the whole stomatognathic system, which includes teeth, supporting structures, neuromuscular system and temporomandibular joints (1-6).

The awareness of these damages motivates the scientific community to conduct studies to develop and evaluate diagnostic methods for more accurate detection of premature occlusal contacts $(6,7)$. Several studies were conducted with the aim of researching the features and performance of materials used in occlusal registrations as well as the accuracy and reliability of existing methods for the identification of these contacts (8-11).

The importance of cone-beam computed tomography (CBCT) must also be emphasized to diagnose changes in the structures of craniofacial complex. This technology brought several advantages, including three-dimensional visualization of different components of the stomatognathic system in high resolution (12). Specifically for occlusion, its coverage in three spatial planes brings great expectations on overcoming deficiencies of other methods used to identify occlusal interference, such as: distortions of dental materials, variability between techniques of manipulation of patients and limited viewing in two dimensions only.
Since CBCT has been proven to be the most accurate modality of three-dimensional image, with the best costbenefit and more conservative dose of radiation (13), the aim of this study was to evaluate the ability to identify occlusal prematurity by the analysis of paraxial CBCT slices.

\section{Material and Methods}

In this study, 16 subjects aged 17 to 25 years were chosen among undergraduate students of Federal University of Uberlândia, Brazil. All subjects presented complete natural dentition (except for third molars), no signs or symptoms of temporomandibular dysfunction or reports of facial trauma, no previous orthodontic or occlusal adjustment. All patients signed an informed consent form, according to the regulations of the Ethics Committee of the Federal University of Uberlândia (CEP-127/2008).

An overall assessment of all components of the stomatognathic system was made initially, followed by the construction of a Lucia's JIG in order to allow the individual analysis in centric relation (14). After using the JIG for $5 \mathrm{~min}$, the dental contacts of each patient were obtained with articulating paper (Accufilm II, Parkell, New York, NY, USA) gripped by a Myller forceps. This procedure was performed by a single trained examiner and rechecked by another. The first interocclusal contact was marked (occlusal prematurity) with the condyles positioned in centric relation by mandibular manipulation 
with the Frontal Technique, proposed by Ramfjord in 1983 (15). The JIG was then ground on its palatal side until obtaining that first occlusal and incisal contacts with the JIG simultaneously. This position was set in the interocclusal device using a tiny amount of acrylic resin to make it a stable reference point for use in the CBCT analysis (16). The CBCT images were obtained using the NewTom 3G tomographer (Quantitative Radiology, Verona, Italy). The patient was accommodated comfortably, protected with plumbiferous apron and scanning was performed with the JIG positioned and the jaw was set in the previously made reference point. The tomographic images were processed using the tomographer's proprietary software, which allowed the production of 1.0-mm-thick paraxial slices, using as reference the centric contention cusps of mandibular premolars and molars.

Paraxial CBCT slices previously selected by the researchers from the entire set of tomographic images obtained in the study were sent to independent trained examiners for analysis. The images selected were the best sequential images of each cusp tip of the premolars, the mesiobuccal and distobuccal cusps of the first and second mandibular molars, on the right and left sides (Fig. 1). Thus, 36 images per individuals were obtained, totalizing 576 images to be analyzed by each examiner.

After signing an informed consent form approved by the local Ethics Committee, 30 professionals, divided into 3 groups, served as examiners of the CBCT scans: 10 dental radiologists, 10 occlusion professors and 10 general practitioners. Each participant received a sheet containing instructions about the research methodology and procedures, an interactive $\mathrm{CD}$ containing the CBCT scans and questionnaires to be answered about the images of all patients. Later, these groups of professionals were divided according to the time of professional experience (less than 5 , between 5 and 10 and over 10 years).

Participants were instructed to visualize the images in dark places. The premature occlusal contacts were

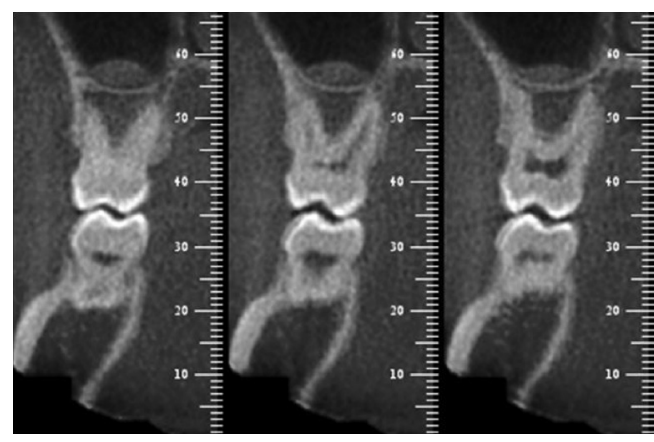

Figure 1. Paraxial CBCT scans for each premolar cusp and mesiobuccal and distobuccal cusps of the first and second molars on both sides (right and left). analyzed bilaterally in all posterior teeth except for the third molars. For every examined tooth, the participant filled a questionnaire with three answer options related to the existence or absence of occlusal prematurity. Thus, the participant would mark "yes" if an occlusal prematurity was observed, "no" if they did not visualize it, and "cannot be determined", a situation that they were asked to justify. Data were analyzed statistically by ANOVA and Scott-Knott test at a significance level of 5\%.

\section{Results}

Intra-examiner agreement was calculated by comparing the assertion of premature occlusal contact compared with the clinical analysis with articulating paper and no statistically significant differences were found $(p<0.05)$.

No statistically significant differences $(p<0.05)$ were found among the groups of professionals of different areas with respect to the success rate. Regarding the subgroups defined according to the time of professional experience, the least experienced professionals presented the lowest success rate while no statistically significant difference was found between the other groups of professionals.

\section{Discussion}

A continuous review of methods and materials used in the identification of occlusal contacts is necessary to achieve a fine occlusal balance. The characteristics and performance of materials used in occlusal records as well as the accuracy and reliability of available methods for identifying these contacts have been extensively investigated. Although it is not unanimous, the most frequently diagnostic criteria used for occlusal disorders are clinical examination and detailed anamnesis performed by an experienced professional (7).

Considering the marking analysis as a gold standard, it could be said that the accuracy obtained with this method is directly related to factors such as position of the chair, use of deprogrammers, training and orientation of the movement to be performed, operator's skills to perform mandibular manipulation, drying of surfaces, intensity of jaw closing, ability of the material used for occlusal registration to mark the contacts clearly and knowledge of the mechanical and functional principles of occlusion. With so many variables there is a clear need for standardizing clinical examination as well as for keeping a constant search for additional resources that enhance information and provide more effective ways of reaching these goals (17-19).

Although clinical examination is generally considered as the gold standard, there still is resistance to adopting it as a definitive diagnosis method, due to the above-mentioned vulnerabilities. For this reason, numerous proposals for occlusal evaluation have been suggested $(6,7,10,11)$. One 
of the most recent technologies that meets the demand for an accurate occlusal examination is CBCT. Currently, its accessible cost, low radiation dose and capacity to generate any type of pre-existing image system in three-dimensional shape, has made this diagnostic method applicable in almost all areas of dentistry, even revealing not previously envisioned perspectives.

In the presence of occlusal interferences, muscles can change the position of the jaw in an attempt to protect the teeth and absorb all muscle strength during the closing movement (6). This pattern of altered muscle activity may prevent the condyles from being properly positioned in the mandibular fossa, making it difficult to reach the CR position. Many techniques are available to assist in obtaining registration in $\mathrm{CR}$, and this study advocated the use of the Lucia's JIG deprogrammer. This preference was due to its ease of fabrication, low cost and scientifically proven capacity to allow muscle relaxation, facilitating mandibular manipulation (20-22).

Wood (23) showed that the recording technique in CR could be easily standardized with practice based on little intra/interoperator variability but carefully assimilated and precisely executed. The choice for the frontal manipulation technique designed by Ramfjord and Ash (1983) is attributed to its high reproducibility and applicability among the record-guided techniques when used gently It is used only to guide the patient properly relaxed while searching for a comfortable CR position, making a hypothetical clockwise condylar displacement $(15,24)$.

This study evaluated the ability of dental professionals to identify occlusal prematurity from paraxial CBCT scans obtained with the patients positioned in CR. For this purpose, 30 examiners were invited to participate in the study and divided into 3 groups, two with professionals from relevant related areas (occlusion and radiology) and one group formed by general dentists, comparing their opinions with the previous first occlusal prematurity identified clinically during jaw closing. In the beginning of this investigation, it was assumed that by confirming the efficacy of this methodology, the set of images generated from a basic tomographic image would be capable to guide the professional to the site and location of the interference in the corresponding images. The results showed an ability to hit on average $50.198 \%$ of agreement between the examiners' opinion and the clinically identified first prematurity. This occurred in a relatively unanimous way, as demonstrated by the agreement between groups. The expectation was that occlusion specialists would obtain a greater percentage of accuracy than radiologists and general practitioners. This actually occurred in the order of 55.595\% correlation for the first group (occlusion), 50.625\% for the second and $44.375 \%$ for the third, although there was no statistically significant difference.

Comparing the level of experience of the examiners, without evidence of significant discrepancy between the results, professionals with more than 10 years of activity had an accuracy of $56.825 \%$, those with between 10 and 5 years of professional practice had $54.861 \%$, and those with less than 5 years had $40.340 \%$ of correct responses, which was expected, despite the quantitative similarity from the statistical point of view. It is important to know that the absence of statistical significance does not imply a lack of differences, especially because a high standard deviation was found, diluting the results of averages in case of reduced samples.

As observed, this possible diagnosis method of prematurity fits more as an additional resource surrounded by limitations, when applied to identify occlusal interferences. Probably, three factors had a substantial involvement in these results: paraxial cut images, sample size and popularity of the method.

The image quality obtained in the paraxial slices was not always accessible. The presence of devices such as metal restorations usually prevented or greatly hindered the identification of possible prematurity in the target areas. This was due to the high atomic number of the metals, which attenuate the $x$-rays much more than the hard and soft tissues. The result is the pronounced presence of radiopaque and bright bands in the form of rays, marginal non-linear gradients and errors in the samples of surface restoration. Consequently, this creates serious difficulties of interpretation in the researched areas by the presence of artifacts (25). For this reason, many professionals justified the impossibility to determine the existence or absence of occlusal prematurity due to the presence of artifacts and lack of sharpness in the images. Conversely, but with the same ability to disable the evaluation of interference, the presence of plastic or resin restorations involving the crowns of the teeth under analysis, generated relevant radiolucent images, which made it impossible to delineate occlusal contours of the investigated teeth, preventing any diagnostic formulation.

Furthermore, features of the images given by the paraxial cuts, lead the researchers to reflect on their ability to identify occlusal interferences as a whole. Since this type of image tends to reveal the dental contour in buccolingual direction (BL), it is clear that its potential to diagnose possible occlusal interference is especially concentrated in hanges in long axis inclinations, in BL direction, or discrepancies in the transverse dimensions of the maxilla and/or jaw. Therefore, interference from purely extrusive dental displacements or changes in the long axis inclination, restricted to the mesiodistal (MD) direction, rarely or never could be evidenced by paraxial 
scans only. Even under this critical thinking of the used CT slice, it emphasizes the impossibility of evaluating precisely the $\mathrm{BL}$ dimension of any tooth that is reversed. However, when the obtained images were free of these limitations, the images were of high quality making it easy to evidence a possible prematurity.

The prospect of this diagnostic method is undeniably promising. The possibility of obtaining three-dimensional reconstructions of any dental-skeletal region and the many varieties of angles of observation that tomography allows open a range of applications specific for Dentistry.

Finally, a 50\% accuracy does not institute nor discard, at first, any diagnostic feature in the initial investigation, but may eventually provide opportunities for future multidirectional ways. Identifying limitations of a new method has the same scientific value of its consolidation as a diagnostic tool. This is how it can be found ways to clarify ideas and upon which science is founded.

According to this study, it may be concluded that the identification of occlusal prematurity by images from paraxial CBCT scans has not demonstrated superiority to clinical analysis by markings. Considering the results obtained with groups of professional participants, it is concluded that the area of professional activity did not influence the analysis of tomographic images; however, the professional experience demonstrated some influence, although not statistically significant.

\section{Resumo}

0 objetivo deste estudo foi avaliar a capacidade de identificação de prematuridades oclusais por meio de imagens obtidas de cortes paraxiais de tomografias computadorizadas de feixe cônico. Para este fim, realizouse um estudo piloto em que 16 pacientes jovens assintomáticos foram submetidos ao exame clínico, incluindo análise oclusal criteriosa, e em seguida foram confeccionados dispositivos desprogramadores individuais ("JIG de Lucia"). Mediante manipulação mandibular e marcação interoclusal com papel carbono (Accufilm) identificou-se clinicamente o contato prematuro em relação cêntrica $(\mathrm{RC})$ de cada paciente. Posteriormente estes dispositivos foram ajustados na posição de contato cêntrico e utilizados durante os exames tomográficos para que se pudessem obter imagens tomográficas na posição de relação cêntrica. Após o processamento das imagens, estas foram analisadas com o intuito de identificar prematuridades oclusais nas imagens visualizadas por 30 profissionais divididos de acordo com as áreas de atuação (Oclusão, Clínica Geral e Radiologia, $n=10$ para cada área) e tempo de exercício profissional ( $<5$; entre 5 e 10; e > 10 anos). Mediante comparação entre os contatos prematuros identificados na análise clínica oclusal e as imagens tomográficas apontadas pelos profissionais como áreas de contatos prematuros, foram calculados os indices de concordância entre essas duas variáveis. Os dados obtidos foram analisados estatisticamente pela Análise de Variância ANOVA e teste de Scott-Knott $(\alpha=0,05)$. Os resultados deste estudo demonstraram que a identificação de prematuridades oclusais por meio de cortes paraxiais de tomografias computadorizadas de feixe cônico mostrou-se como um método de confiabilidade média.

\section{References}

1. Brandini DA, Trevisan CL, Panzarini SR, Pedrini D. Clinical evaluation of the association between noncarious cervical lesions and occlusal forces. J Prosthet Dent 2012;108:298-303.

2. Oltramari PV, Conti AC, Navarro R de L, Almeida MR, Almeida-Pedrin RR, Ferreira FP. Importance of occlusion aspects in the completion of orthodontic treatment. Braz Dent J 2007;18:78-82.

3. Wang $\mathrm{C}$, Yin X. Occlusal risk factors associated with temporomandibular disorders in young adults with normal occlusions. Oral Surg Oral Med Oral Pathol Oral Radiol 2012;114:419-423.

4. Strini PJ, Machado NA, Gorreri MC, Ferreira A de F, Sousa G da C, Fernandes Neto AJ. Postural evaluation of patients with temporomandibular disorders under use of occlusal splints. J Appl Oral Sci 2009;17:539-543.

5. Branschofsky M, Beikler T, Schäfer R, Flemming TF, Lang H. Secondary trauma from occlusion and periodontitis. Quintessence Int 2011;42:515-522.

6. Dawson $\mathrm{PE}$, Arcan M. Attaining harmonic occlusion through visualized strain analysis. J Prosthet Dent 1981;46:615-622.

7. Baba K, Tsukiyama Y, Clark GT. Reliability, validity, and utility of various occlusal measurement methods and techniques. J Prosthet Dent 2000;83:83-89.

8. Chai J, Leong DK, Pang IC. An investigation of the rheological properties of several interocclusal registration materials. J Prosthodont 1994;3:134-137.

9. Pagnano VO, Bezzon OL, de Mattos MG, Ribeiro RF. A clinical evaluation of materials for interocclusal registration in centric relation. Braz Dent J 2000;11:41-47.

10. Carey JP, Craig M, Kerstein RB, Radke J. Determining a relationship between applied occlusal load and articulating paper mark area. Open Dent J 2007:1:1-7.

11. Koos B, Godt A, Schille C, Göz G. Precision of an instrumentation-based method of analyzing occlusion and its resulting distribution of forces in the dental arch. J Orofac Orthop 2010;71:403-410.

12. Adibi S, Zhang W, Servos T, O'Neill PN. Cone beam computed tomography in dentistry: what dental educators and learners should know. J Dent Educ 2012;76:1437-1442.

13. Donovan TE, Anderson $\mathrm{M}$, Becker $\mathrm{W}$, Cagna DR, Hilton TJ, Rouse J. Annual review of selected scientific literature: report of the Committee on Scientific Investigation of the American Academy of Restorative Dentistry. J Prosthet Dent 2009;102:10-45.

14. Lucia V0. A technique for recording centric relation. J Prosthet Dent 1964;14:492-505.

15. Ramfjord S, Ash M. Occlusion. 3rd ed. Philadelphia: WB Saunders; 1983.

16. Henriques JC, Fernandes Neto AJ, Almeida $G$ de $A$, Machado NA, Lelis ER. Cone-beam tomography assessment of condylar position discrepancy between centric relation and maximal intercuspation. Braz Oral Res 2012;26:29-35.

17. Davies SJ, Gray RM. The examination and recording of the occlusion: why and how. Br Dent J 2001;191:291-296,299-302.

18. McCullock AJ. Making occlusion work: I. Terminology, occlusal assessment and recording. Dent Update 2003;30:150-157.

19. Qadeer S, Kerstein R, Kim RJ, Huh JB, Shin SW. Relationship between articulation paper mark size and percentage of force measured with computerized occlusal analysis. J Adv Prosthodont 2012;4:7-12.

20. Karl PJ, Foley TF. The use of a deprogramming appliance to obtain centric relation records. Angle Orthod 1999;69:117-125.

21. Keshvad A, Winstanley RB. An appraisal of the literature on centric relation. Part I. J Oral Rehabil 2000;27:823-833.

22. Nassar MS, Palinkas $M$, Regalo $S C$, Sousa $L G$, Siéssere $S$, Semprini $M$, et al.. The effect of a Lucia jig for 30 minutes on neuromuscular reprogramming, in normal subjects. Braz Oral Res 2012;26:530-535.

23. Wood DP, Elliott RW. Reproducibility of the centric relation bite registration technique. Angle Orthod 1994;64:211-220.

24. Alvarez MC, Turbino ML, Barros C, Pagnano VO, Bezzon OL. Comparative study of intermaxillary relationships of manual and swallowing methods. Braz Dent J 2009;20:78-83.

25. Bechara BB, Moore WS, McMahan CA, Noujeim M. Metal artifact reduction with cone beam CT: an in vitro study. Dentomaxillofac Radiol 2012;41:248-253. 